\title{
MANAJEMEN SAMPAH KOTA DI KABUPATEN ACEH BARAT PROVINSI ACEH
}

\section{City Waste Management In Aceh Barat District Aceh Province}

\author{
Azwar $^{1}$ \\ ${ }^{1}$ Fakultas Kesehatan Masyarakat Universitas Teuku Umar \\ *(azwar@utu.ac.id)
}

\begin{abstract}
Abstrak
Sampah yang tidak dikelola merupakan sumber pencemar lingkungan dan tempat berkembangnya berbagai macam bakteri, pathogen, parasit dan sarang berbagai vektor.Pencemaran lingkungan yang disebabkan oleh sampah yang terjadi di kota Meulaboh Kabupaten Aceh Barat dapat terlihat dengan banyaknya ditemukan sampah yang dibuang tidak pada tempatnya sehingga menimbulkan kesan kumuh dan kotor dan menghasilkan bau yang tidak sedap.Penelitian Environmental Health Risk Assessment (EHRA) tahun 2012 menunjukkan bahwa sekitar 78,1\% masyarakat Kabupaten Aceh Barat belum menerima layanan pengangkutan sampah, hal ini menggambarkan bahwa manajemen sampah kota di Kabupaten Aceh Barat belum berjalan dengan baik.

Tujuan Penelitian ini adalah untukmengidentifikasi kesesuaian pengelolaan sampah dengan peraturan dan perundang-undangan tentang manejemansampah.Jenis penelitian kualitatif dengan rancangan studi kasus di kota Meulaboh.Subjek Penelitian terdiri dari 4 orang penjabat eksekutif pemerintah Kabupataen Aceh Barat dan 7 orang tokoh masyarakat.Data dikumpulkan melalui observasi dan wawancara mendalam.

Hasil penelitian menunjukkan bahwa masih terbatasnya anggaran dalam manajemansampah.Umumnya masyarakat masih kurang terlibat dalam pengelolaan sampah dan cenderung melimpahkan tanggung jawab pengelolaan sampah kepada pemerintah.

Kesimpulan Pengelolaan sampah di Kabupaten Aceh Barat belum sepenuhnya sesuai dengan peraturan dan perundang-undangan yang berlaku.Perlu meningkatkan anggaran untuk pengelolaan sampah di Kabupaten Aceh Barat.
\end{abstract}

Kata Kunci: Sampah, Manajemen Sampah

\section{ABSTRACT}

Unmanaged waste is a source of polluting the environment and a place for the development of various kinds of bacteria, pathogens, parasites and nests of various vectors. Environmental pollution caused by garbage that occurs in the city of Meulaboh, West Aceh regency can be seen by the large amount of trash that is thrown out of place causing the impression of being dirty and dirty and producing a bad odor. The Environmental Health Risk Assessment (EHRA) study in 2012 shows that around $78.1 \%$ of the people of West Aceh Regency have not received waste transportation services, this illustrates that municipal waste management in West Aceh Regency has not goes well.

The purpose of this study was to identify the suitability of waste management with regulations and legislation regarding waste management. The type of qualitative research was a case study design in the city of Meulaboh. The research subjects consisted of 4 executive officers of the Aceh Barat District Government and 7 community leaders. and in-depth interviews.

The results showed that the budget is still limited in waste management. Generally, the community is still less involved in waste management and tends to delegate responsibility for waste management to the government. 
Conclusion Waste management in West Aceh District has not been fully in accordance with the prevailing laws and regulations. It is necessary to increase the budget for waste management in West Aceh Regency.

Keywords: Garbage, Waste Management

\section{PENDAHULUAN}

Data dari Bank Dunia mengungkapkan akan terjadi peningkatan jumlah sampah pada negara-negara di dunia sebesar 70 persen dari tahun 2012 sampai dengan tahun 2025, dengan jumlah sampah sebesar 1,3 miliar ton pertahun menjadi 2,2 miliyar ton pertahun(Purwiningsih, 2014).

Luas wilayah dan besarnya jumlah penduduk akan berpengaruh pada peningkatan volume sampah yang dihasilkan (Manik, 2009). Kabupaten Aceh Barat memiliki wilayah yang cukup luas dengan jumlah penduduk yang terus meningkat. Menurut data Badan Pusat Statistik (BPS)Kabupaten Aceh Barat memiliki luas wilayah mencapai 2.927,95 $\mathrm{KM}^{2}$, terdiri dari 12 Kecamatan, 33 Mukim, 322 Desa dan memiliki penduduk sebanyak 193.791jiwa(BPS Aceh Barat, 2016). Semakin banyak jumlah penduduk semakin banyak aktivitas sosial ekonomi dan budaya yang dilakukan, semakin banyak energi yang dikonsumsi dan limbah atau sampah yang dihasilkannya pun meningkat (Wardi, 2011).

$$
\text { Badan Lingkungan Hidup dan }
$$

Kebersihan (BLHK) Kabupaten Aceh Barat adalahkelembagaan yang dibentuk oleh pemerintahan Kabupaten Aceh Barat berdasarkan Qanun Kabupaten Aceh Barat Nomor 4 Tahun 2013 Tentang Susunan Organisasi Dan Tata Kerja Lembaga Teknis
Daerah Kabupaten Aceh Barat. BLKH Kabupaten Aceh Barat berwenang dan bertanggung jawab dalam penanganan sampah.Salah satu penjabaran wewenang dan tanggung jawab tersebut adalah melaksanakan pelayanan sampah.Namun, berdasarkan hasilpenelitian Enviromental Health Risk Assessment (EHRA) tahun 2012,pelayanan inibelum mampu menjangkau keseluruh lapisan masyarakat. Hasil penelitian inimenunjukkan bahwa sekitar 21,4\% dari total rumah tangga di Kabupaten Aceh Barat mengakui menerima layanan pengangkutan. Sementara, sekitar $78,1 \%$ melaporkan belum menerima layanan pengangkutan dan sebesar $0,5 \%$ tidak memberikan komentarnya (Strategi Sanitasi Kabupaten Aceh Barat, 2012).

Hasil observasi awal yang dilakukan oleh peneliti, menunjukkan bahwapelayanan sampah sampai saat ini masih terbatas pada jalan-jalan utama, kawasan perkantoran, pasar dan pertokoan, sedangkan pada daerah pemukiman penduduk masih belum semua terjangkau.Lebih lanjut, Pemerintah Kabupaten Aceh Barat belum memiliki Tempat Pembuangan Sementara - Reduce, Reuse, Recycle (TPS 3R)untuk menampung dan pengolahan sampah, akibatnya banyak ditemukan sampah yang dibuang tidak pada tempatnya.Penumpukan sampah tersebut menimbulkan kesan kumuh dan kotor, 
menghasilkan bau tidak sedap serta daerah yang becek.

Keberadaan sampah bila tidak dikelola secara baik dan benar juga berdampak terhadap kesehatan, baik yang disebabkan karena kontak langsung dengan sampah, terutama sampah yang mengandung kuman pathogen sehingga yang dapat menimbulkan penyakit, maupun secara tidak langsung akibat dari proses pembusukan, pembuangan dan pembuangan sampah (Soemirat, 2014).Menurut data Dinas Kesehatan Kabupaten Aceh Barat kasus penyakit diare pada tahun 2014 berjumlah 4.612 kasus dan terjadi peningkatan 57.9\% pada tahun 2015 atau berjumlah 7.965 kasus. Penyakit demam berdarah dengue (DBD) ditemukan 83 kasus pada tahun 2014 dan 59 kasus tahun 2015. Penyakit malaria ditemukan sebanyak 458 kasus pada tahun 2014 dan 356 kasus tahun 2015 (Dinas Kesehatan Kabupaten Aceh Barat, 2016).

\section{METODE}

Penelitian ini menggunakan jenis penelitian kualitatif, yang bertujuan untuk mendeskripsikan manajemen sampah di kota Meulaboh dan menggunakan rancangan penelitian studi kasus. Subjek penelitian didapatkan dengan menggunakan metode purposive sampling yaitu pengambilan sampel berdasarkan pada pertimbangan yang sesuai dengan maksud dan tujuan penelitian (Sukandarrumidi, 2012) yang terdiri dari orang-orang yang bertanggung jawab dalam pengelolaan sampah kota di Kabupaten Aceh Barat.Data dianalisis dengan cara menyajikan berdasarkan kategori jawaban responden dalam bentuk kuotasi, dikelompokkan dan memberi kode untuk menyampaikan kejadian yang ada sehingga mendapatkan hasil penelitian. Hasil dari wawancara yang di dapatkan untuk dianalisis, dipertajam kembali dengan hasil observasi ataupun studi data sekunder.

\section{HASIL}

\section{a. Kondisi Sampah di Kota Meulaboh}

Sampah di kota Meulaboh terdiri dari sampah organik dan sampah non organik. Jenis sampah yang ditemukan berupa sampah plastik, kardus, kertas, kayu, sisa makanan, kaca, botol minuman, kaleng bekas, peralatan bekas rumah tangga dan lainnya.Jenis sampah mendominasi di kota Meulaboh berupa sampah organik yaitu sisa makanan dan potongan sayur jika di bandingkan dengan kayu, ranting maupun daun-daunan. Sampah non organik yang berupa plastik dan botol minuman juga merupakan suatu hal yang sangat meresahkan karena sering ditemui berserakan hampir di semua lingkungan, bukan hanya pada tong sampah dan TPS yang ada.

Jumlah sampah di Kabupaten Aceh Barat tidak memiliki catatan tertulis. Sampah yang di angkut dan dibuang ke TPA tidak pernah di timbang karena pemerintah Kabupaten Aceh Barat belum memiliki sumber daya dan sarana penimbangan sampah.Untuk memastikan jumlah sampah di Kabupaten Aceh Barat, peneliti menghitung jumlah armada yang mengangkut sampah ke TPA dan 
mengukur rata-rata isi bak/kontainer armada

tersebut. Dapat dilihat pada Tabel1:

Tabel. 1 Distribusi Volume Armada Pengangkut Sampah di TPA Kabupaten Aceh Barat

\begin{tabular}{clccc}
\hline No & \multicolumn{1}{c}{ Jenis Armada } & Unit & Volume/Unit & Total Volume \\
\hline 1 & Dump Truck & 10 & $5,7 \mathrm{~m}^{3}$ & $57 \mathrm{~m}^{3}$ \\
2 & Open Pic Up/L.300 & 5 & $4,42 \mathrm{~m}^{3}$ & $22,1 \mathrm{~m}^{3}$ \\
3 & Amroll & 3 & $6,8 \mathrm{~m}^{3}$ & $20,4 \mathrm{~m}^{3}$ \\
\hline Total & 18 & & $99,5 \mathrm{~m}^{3}$ \\
\hline
\end{tabular}

Dari Tabel. 1 dapat di lihat bahwa jumlah armada pengangkut sampah yang masuk ke TPA berjumlah 18 unit. Jumlah sampah rata-rata yang di angkut menggunakan armada jenis dump truck sebanyak $57 \mathrm{~m}^{3} /$ hari, armada jenis amroll sebanyak $20,4 \mathrm{~m}^{3} /$ hari dan armada jenis open pic up/L.300 sebanyak 22,1 $\mathrm{m}^{3}$, maka total sampah yang di angkut ke TPA Kabupaten Aceh Barat sebanyak $\pm 99,5$ $\mathrm{m}^{3} /$ hari.

\section{b. Sumber Daya Manusia}

Dalam pelaksanaan manajemn sampah di kota Meulaboh yang merupakan tugas dan wewenang Badan Lingkungan Hidup dan Kebersihan Kabupaten Aceh Barat, sampai saat ini didukung oleh sumber daya manusia yang berstatus sebagai pegawai kontrak/tidak tetap yang berjumlah 143 orang. Dari jumlah total tersebut sumber daya manusia yang terbanyak adalah kernet armada kebersihan yaitu berjumlah 48 dan penyapu jalan berjumlah 44 orang. Sumber daya manusia ini sudah cukup memenuhi karena telah mampu mencakup seluruh wilayah kerja pelayanan sampah di Kabupaten Aceh Barat. Jumlah sopir armada kebersihan berjumlah 26 orang dan juga sudah cukup memenuhi, karena jumlah armada kebersihan di Badan Lingkungan Hidup dan Kebersihan Kabupaten Aceh Barat sampai saat ini berjumlah 18 unit.

\section{c. Sarana dan Prasarana}

1) Sarana Pengangkutan

$$
\text { Sarana pengangkutan sampah }
$$
pemerintah Kabupaten Aceh Barat telah menyiapkan berbagai jenis armada pengangkutan sampah yang beroperasi di wilayah pelayanan sampah Kabupaten Aceh Barat. Untuk jenis dan jumlah armada tersebut dapat dilihat pada tabel berikut:

Tabel 2. Distribusi Jumlah Armada Pengangkut Sampah Badan Lingkungan Hidup dan Kebersihan Kabupaten Aceh Barat

\begin{tabular}{clc}
\hline No & Jenis Armada & Jumlah \\
\hline 1 & Dump Truck & 10 \\
2 & Amroll & 3 \\
3 & Open Pic Up/L300 & 5 \\
4 & Becak Sampah & 1 \\
5 & Buldoser & 1 \\
6 & Excavator & 3 \\
\hline
\end{tabular}

Sumber: Kantor BLHK Kabupaten Aceh BaratTahun 2017 
Pada Tabel 2 dapat di lihat bahwa armada dalam pengelolaan sampah yang dimiliki Badan Lingkungan Hidup dan Kebersihan Kabupaten Aceh Barat untuk mengangkut sampah berjumlah 18 unit serta didukung oleh 1 unit becak sampah yang beroperasi di wilayah pelayanan pengangkutan sampah dan 4 unit lainnya berupa armada jenis alat berat ( buldoser dan excavator) yang beroperasi di TPA.

Jumlah armada amroll masih belum cukup terpenuhi untuk pengangkut sampah yang berada di TPS kontainer. BLHK Kabupaten Aceh Barat memiliki 24 unit kontainer yang harus di angkut dan dikosongkan setiap hari, namum karena jumlah armada amroll yang 3 unit sehingga hanya dapat mengangkut kontainer 3 unit perhari.waktu pengangkutan setiap pagi pukul $08.30-10.00$ wib dengan frekuensi pengangkutan sampah dilakukan hanya 1 kali dalam sehari. Hal ini disebabkan masih kurangnya anggaran operasional pengelolaan sampah di Kabupaten Aceh Barat. Berikut Berikut adalah kutipan dari perspektif informan:

"Pengangkutan tidak,tapi
pembersihan ada, itulah kita
tidak bisa maksimal
pengangkutan dua kali, ini
menyangkut biaya angkut, biaya
BBM dan segala

macamkan.Tapi nanti kalau kedepan memang pendukung mencukupi, anggaran daerah memadai bisa jadi kita dua kali sehari ..." (informan B3).

Dari hasil wawancara tersebut dapat di ketahui bahwa pengangkutan sampah hanya dapat dilakukan satu kali pengangkutan dalam sehari, hal ini disebabkan masih terkendalanya biaya operasional pengelolaan sampah di Kabupaten Aceh Barat terutama dalam pengangkutan sampah.

2) Sarana Pewadahan dan Pemindahan Sampah

Kabupaten Aceh Barat belum memiliki tempat sampah yang dapat digunakan untuk tempat memilah sampah.Pewadahan sampah berupa pewadahan komunal yang disediakan BLHK diperuntukkan pada fasilitas umum.Pewadahan individu yang diperuntukkan pada masyarakat dan ditempatkan di pinggir jalan di depan rumah penduduk, namun jumlahnya masih sangat terbatas bila dibanding dengan jumlah penduduk dan jumlah sampah yang dihasilkan. Berikut adalah kutipan dari perspektif informan:

“...Cuma kita kendalanya ini bak sampah (tempat sampah), tempat sampah yang disediakan oleh BLHK tidak mencukupi, kan banyak kita lihat rumah 
tangga itu menggunakan keranjang, ember atau tempat yang lain yang bisa menampung sampah yang diangkut" (Informan K1)

"Tergantung rumah, nanti ada keranjang ada juga ember biasa yang tidak digunakan lagi, itu bervariasi dia, kalau yang disediakan oleh pemerintah (BLHK) itu bentuknya permanen yang sudah di cat (warna kuning)" (Informan K4)

Untuk bisa menanggulangi kekurangan tempat sampah, masyarakat menyiapkan tempat sampah secara pribadi baik berupa keranjang, ermber atau beberapa jenis lainnya yang bisa dijadikan tempat untuk menampung sampah.Sedangkan tempat sampah dari BLHK terbuat dari drum dan di cat warna kuning atau biru sebagai tanda milik BLHK Kabupaten Aceh Barat, rata-rata memiliki tinggi $57 \mathrm{~cm}$ dan diameter $62 \mathrm{~cm}$ dengan kapasitas 172 liter.

Menurut SNI 19-2454-2002 yang di kutip dalam Dalam Lampiran II Peraturan Menteri Pekerjaan Umum RI Nomor 03/Prt/M/2013 Tentang Penyelenggaraan Prasarana dan Sarana Persampahan Dalam Penanganan Sampah Rumah Tangga dan Sampah Sejenis Sampah Rumah Tangga menyebutkan bahwa wadah sampah yang berjenis bin/drum dengan kapasitas 40-120 liter untuk $1 \mathrm{KK}$ penghasil sampah, kapasitas minimal 120-240 liter untuk 2-3 kk penghasil sampah dan kapasitas minimal 240 liter untuk 4-6 kk penghasil sampah.

\section{PEMBAHASAN}

\section{Manajemen Sampah di Kota Meulaboh}

\section{a. Pemilahan}

Dari hasil penelitian didapatkan bahwa sampah yang dihasilkan baik yang berasal dari tempat/tong sampah (pemukiman), yang dikumpul di pinggir jalan maupun yang berada di TPS langsung diangkut ke TPA tanpa dilakukan pemilahan. Umumnya masyarakat tidak memanfaatkan sampah untuk digunakan kembali dan/atau di daur ulang sesuai dengan jenis sampah. Hal ini disebabkan oleh kurangnya sosialisasi dan pelatihan dari BLHK Kabupaten Aceh Barat tentang pengelolaan sampah. Padahal dalam Undang-Undang No.18 Tahun 2008 Tentang Pengelolaan Sampah Pasal 8 disebutkan bahwa pemerintah harus menumbuhkembangkan dan meningkatkan kesadaran masyarakat dalam pengelolaan sampah.

Pemerintah daerah (BLHK Kabupaten Aceh Barat) juga belum memiliki sarana pewadahanpemilahan 
sampah sebagaimana yang diamanatkan dalam Peraturan Pemerintah No.81 Tahun 2012 Tentang Pengelolaan Sampah Rumah Tangga dan Sampah Sejenis Rumah Tangga Pasal 17 yang menyebutkan bahwa pemerintah kabupaten/kota wajib menyediakan sarana pemilahan sampah.Ketidaktersediaan sarana dan prasarana pemilahan dan pengolahan sampah mengakibatkan penyelenggaran pengelolaan sampah di Kabupaten Aceh Barat masih belum baik. Pemilahan sampah sangat penting dilakukan, selain akan mudah di ambil dan digunakan kembali dan/atau di daur ulang sehingga dapat mengurangi jumlah sampah di TPA, pemilahan sampah juga akan membuat mudah dalam proses pengolahan akhir di TPA. Hasil Penelitian (Riswan, 2011) didapatkan bahwa dengan melakukan kegiatan pemilahan sampah di Kecamatan Daha Selatan, Kalimantan Selatan dapat menurunkan volume sampah di daerah tersebut sebesar $9 \%$ setiap tahunnya.

\section{b. Pengumpulan}

Pengumpulan sampah yang berada di jalan dan tempat-tempat umum yang berupa daun-daun, plastik, kertas atau sampah lainnya disapu oleh petugas kebersihan kemudian di kumpulkan di pinggir-pingir jalan dan selanjutkannya diambil dan dimasukkan ke dalam armada pengangkut sampah baik drum truck ataupun open pic up/L300 kemudian diangkut menuju TPA. Sedangkan sampah yang di hasilkan dari rumah tangga, umumnya dikumpulkan di dalam plastik, keranjang atau tempat sampah. Sampah-sampah tersebut belum dipilahkan baik berupa sampah organik maupun yang berupa sampah nonorganik. Begitu juga dengan sampah yang berasal dari daun-daun pohon yang berada di halaman rumah atau disekitar rumah, sampah-sampah tersebut dikumpulkan menjadi satu dengan sampah domestik dan dimasukkan ke tempat/tong sampah.

Akibat kurangnya sarana pewadahan sampah, masih terdapatnya masyarakat yang belum tertip dalam membuang sampah di Kabupaten Aceh Barat.Di Zimbabwe, permasalahan yang sama juga di hadapi oleh Depertamen Pengelola Limbah di Negara tersebut yaitu kurangnya sarana prasarana pengelolaan sampah pengelolaan sampah, meningkatnya jumlah sampah yang diakibatkan oleh bertambahnya jumlah penduduk serta perilaku masyarakat masih membuang sampah sembarangan (Chikobvu and Makarati, 2011). Permasalahan pengelolaan sampah juga terjadi di Kano Metropolis, Nigeria. Permasalahan persampahan di negara ini adalah ketersediaan anggaran, kebijakan, sarana prasarana dan teknik 
pengelolaan sampah (Butu and Mshelia, 2014).

\section{c. Pengangkutan.}

Pengangkutan sampah di kota Meulaboh sepenuhnya dilakukan oleh Badan Lingkungan Hidup dan Kebersihan Kabupaten Aceh Barat melalui petugas pengangkutan dengan menggunakan armada pengangkut sampah. Hal ini telah sesuai dengan Peraturan Pemerintah No. 81 Tahun 2012 Tentang Pengelolaan Sampah Rumah Tangga dan Sampah Sejenis Sampah Rumah Tangga Pasal 19 Ayat 1 yang menyebutkan bahwa pengangkutan sampah dilakukan oleh pemerintah kabupaten/kota.

\section{d. Tempat Pembuangan Akhir (TPA) \\ Pengelolaan TPA Kabupaten}

Aceh Barat masih menggunakan metode open dumping atau pembuangan terbuka. Dalam Undang-Undang No. 18 Tahun 2008 Tentang Pengelolaan Sampah Bab XVI Pasal 44 Ayat 2 ditegaskan bahwa pemerintah daerah harus menutup TPA sampah yang menggunakan sistem pembuangan terbuka paling lama 5 (lima) tahun sejak berlakunya Undang-Undang ini. Hal ini menunjukkan bahwa pengelolaan sampah di TPA Kabupaten Aceh Barat tidak sesuai lagi dengan perundangundangan.
Pengeloaan sampah dengan menggunakan metode open dumping berpotensi menimbulkan dampak buruk terhadap lingkungan dan kesehatan lingkungan, diantaranya menimbulkan pertumbuhan vektor penyakit, pencemaran udara, estetika lingkungan yang tidak baik dan bau yang tidak sedap serta pencemaran air lindi(Daryanto, 2015). Menurut Purwiningsih (2014) dampak dari TPA yang menggunakan metode open dumpingselain lahan pemrosesan akhir semakin sempit juga dapat menyebabkan kerusakan lingkungan karena bau yang ditimbulkan dan mengundang banyak vektor penyakit serta terkontaminasi air bawah tanah yang disebabkan oleh air lidi dari TPA tersebut.

Kegiatan penimbunan sampah di TPA sebaiknya menggunakan metode sanitary landfill. Menurut Riyanto (2012) metode ini merupakan metode standar yang dipakai secara internasional dimana menutup sampah dengan lapisan tanah yang dilakukansetiap hari pada akhir pembuangan sampah sehingga tidak akanterlihat adanya timbunan sampah.

\section{KESIMPULAN}

Manajemen sampah di kota Meulaboh belum sepenuhnya sesuai dengan peraturan perundangan- 
undangan yang berlaku di tingkat nasional hal ini masih terkendala dengan masih kurangnya anggaran dalam menajemen sampah di kota Meulaboh.Keterlibatan dan partisipasi masyarakat masih sangat kurang dalam manajemen sampah, hal ini disebabkan belum maksimal kegiatan sosialisasi dilakukan pemerintah Kabupaten Aceh Barat terkait dengan pengelolaan sampah, sehingga masyarakat cenderung melimpahkan tanggung tentang pengelolaan sampah kepada pemerintah.

\section{DAFTAR PUSTAKA}

1. Sukandarrumidi, 2009. Rekayasa Gambut, Briket Batubara, dan Sampah Organik, Yogyakarta: UGM Press.

2. Tobing, I.S., 2005. Dampak sampah terhadap kesehatan lingkungan dan manusia. In pp. 1-9.

3. Purwiningsih, Wahyu, D., 2014. Pengelolaan Sampah di Kota Ternate Provinsi Maluku Utara. Universitas Gadjah Mada.

4. BPS Aceh Barat, 2016. Aceh Barat Dalam Angka 2016, Meulaboh: BPS Kabupaten Aceh Barat.

5. Wardi, N., 2011. Pengelolaan Sampah Berbasis Sosial Budaya: Upaya Mengatasi Masalah Lingkungan Di Bali. Bumi Lestari, 11(1), pp.167177.

\section{SARAN}

Memberikan sosialisasi dan pelatihan pengelolaan sampah kepada masyarakat dengan pendekatan ekonomi, sehingga masyarakat bisa termotivasi dan memiliki ketrampilan dalam pemanfaatan sampah menjadi barang yang bernilai jual tinggi.Untuk peneliti selanjutnyadapat mencari informasi lebih dalam tentang jumlah sampah yang dihasilkan di Kabupaten Aceh Barat serta manajemen pengelolaan sampah di TPA Kabupaten AcehBarat.

6. Strategi Sanitasi Kabupaten Aceh Barat., 2012. Aceh Barat

7. Soemirat, J., 2014. Kesehatan Lingkungan 9th ed., Yogyakarta: UGM Press.

8. Sukandarrumidi, 2012. Metodologi Penelitian: Pentunjuk Praktis untuk peneliti pemula 4th ed., Yogyakarta: UGM Press.

9. Suyanto, Edy, Endriatmo Soetarto, Sumardjo, and Hartriasri Hardjomidjojo, 2014. Analysis On Local WisdomBased Green Community Participation Supporting The Developmental Program At The Green City- Purwokerto Indonesia (A Case Study Of Household Waste Management). International Journal of Research In Earth \& Environmental Sciences, 2(5), pp.1-9.

10. Sharholy, M. and Ahmad, K., 2008. Municipal solid waste 
management in Indian cities A review. Waste Management, Vol. 28, pp.459-467.

11. Chikobvu, Dellson. Makarati, F., 2011. The Challenges of Solid Waste Disporsal in Rapidly Urbanizing Cities: A Case of Highfield Suburb in Harare, Zimbabwe. Journal of Sustainable Development in Africa, Vol.13(7), pp.184-199.

12. Butu, A. Mshelia, S., 2014. Municipal Solid Waste Disporsal and Environmental Issue in Kano Metroolis, Nigeria. British Journal of Environmental Sciences, Vol. 2(2), pp.10-26.

13. Riswan, Henna Ria Sunoko, A.H., 2011. Pengelolaan Sampah Rumah Tangga di Kecamatan Daha Selatan. Ilmu Lingkungan, Vol.9(1).

14. Rizal, M., 2011. Analisis Pengelolaan Persampahan Perkotaan (Sudi kasus pada Kelurahan Boya Kecamatan
Banawa Kabupaten Donggala). Smartek, 9(2), pp.155-172.

15. Bahri, S., 2012. Pelaksanaan Syari'at Islam di Aceh sebagai bagian wilayah Negara Kesatuan Republik Indonesia ( NKRI ). Dinamika Hukum, Vol.12.

16. Arli, D. \& Tjiptono, F., 2014. The End of Religion? Examining the Role of Religiousness , Materialism , and Long-Term Orientation on Consumer Ethics in Indonesia. J Bus Ethics, pp.385-400.

17. Vitell, S.J., Paolillo, J.G.P. \& Singh, J.J., 2005. Religiosity and Consumer Ethics. Journal of Business Ethics.

18. Mulasari, A., 2016. Pengelolaan Sampah Berwawasan Kesehatan Masyarakat berdasar Pemberdayaan Masyarakat dan Dukungan Pemerintah di Kota Yogyakarta. Universitas Gadjah

Mada. 